\title{
Effects of oral phytoextract intake on phenolic concentration and redox homeostasis in murine encephalic regions
}

\author{
M. C. Cittadini ${ }^{1,2}$, A. M. Canalis ${ }^{1}$, C. Albrecht $^{1,2}$, E. A. Soria ${ }^{1}$ \\ ${ }^{1}$ INICSA, Universidad Nacional de Córdoba - CONICET, Córdoba, Argentina, ${ }^{2}$ Instituto Nacional del Cáncer, \\ Ministerio de Salud de la Nación, Buenos Aires, Argentina
}

\begin{abstract}
Vegetable infusions ( $\mathrm{VI}$ ) are one of the main phenolic sources for humans. They may act as antioxidants in the central nervous system, but data about their effect are insufficient. The main objective of the study was to determinate the effects of oral VI of Argentinean plants on phenolic concentration and redox homeostasis in different murine encephalic regions. Redox changes (peroxides -HP-, anion superoxide -SO- and $\gamma$-glutamyltranspeptidase activity) and tissue phenolics were assessed in Balb/c mice of both sexes treated with the following VI extracts: Lantana grisebachii Seckt. var. grisebachii (Verbenaceae) (LG), Aspidosperma quebracho-blanco Schltdl. (Apocynaceae) (AQB), and Ilex paraguariensis A. St.-Hil. (Aquifoliaceae) (IP). Brain (telencephalon and diencephalon), midbrain, brainstem, and cerebellum were studied (analysis of variance, $P<0.05$ ). A redox homeostasis depending on an appropriate phenolic balance was detected after marker analysis. Under situations without exogenous challenges, the excessive or deficient levels were deleterious on each region. This finding was confirmed independently of the utilized phytoextracts. LG and AQB caused such phenolic imbalance and triggered oxidative stress. IP group showed region-specific differential redox effects. Overall, the last extract exhibited the best redox profile when the complete encephalon was analyzed. Since this plant has sanitary impact due to its high human intake, new studies about it are warranted.
\end{abstract}

Keywords: Central nervous system, Ilex paraguariensis, Infusion, Oxidative stress, Polyphenol

\section{Introduction}

Oxidative damage has been defined as 'the biomolecular damage caused by attack of reactive species upon the constituents of living organisms', ${ }^{1}$ with the central nervous system (CNS) being particularly susceptible to this damage. ${ }^{2-4}$ Regarding these reactive species, superoxides and hydroperoxides are important oxidizing compounds but have a deleterious effect on living tissues if they are over-produced. ${ }^{5}$ This process is involved in the pathogenesis of several neurodegenerative illnesses, such as Parkinson's disease and Alzheimer's disease. $^{3-4,6-8}$

The redox status of CNS may be regulated by diet ingredients. ${ }^{2,6,9,10}$ In this sense, vegetable foods contain numerous antioxidant molecules, such as phenolic compounds, and other phytochemicals and nutrients. ${ }^{5,11,12}$ These substances, referred to generally as phytonutrients, could exert protective effects through free radical inactivation, modulation of

Correspondence to: Elio A. Soria, Facultad de Ciencias Médicas, Universidad Nacional de Córdoba; CONICET.

Email: easoria@fcm.unc.edu.ar cellular processes as proliferation, apoptosis, and redox balance in CNS. ${ }^{13,14}$ However, solid experimental data are not enough in order to establish the optimal phytochemical intake and other nutritional concerns to achieve those desirable health effects. ${ }^{15}$

In nature, there are many phenolic compounds, including phenolic acids, flavonoids, stilbenes, and lignans. ${ }^{16,17}$ Their dietary sources are fruits, oil seeds, and different plants, which are consumed as infusions or teas. ${ }^{4,17}$ In general, infusions are one of the main phenolic sources, with a strong antioxidant activity against free radicals, nitrite oxide, and lipid oxidation., ${ }^{2,4}$ Nonetheless, their bioactivity may depend on the phytochemical capacity to reach the different CNS regions: the brain (telencephalon and diencephalon), midbrain, cerebellum, and the brainstem. For example, some tea catechins are able to penetrate the blood-brain barrier (BBB) in low levels, showing a good bioavailability after oral administration, ${ }^{2,7,18}$ also reducing stressrelated beta-amyloid peptides in neurons. ${ }^{19}$

Reports about Argentinean plants have identified species with antioxidant activity and ethnobotanical uses. ${ }^{11,20}$ Among them, Lantana grisebachii Seckt. 
var. grisebachii (Verbenaceae) (LG), Aspidosperma quebracho-blanco Schltdl. (Apocynaceae) (AQB), and Ilex paraguariensis A. St.-Hil. (Aquifoliaceae) (IP) were selected to be assayed as neuroprotective candidates. Moreover, the in vivo analysis in the CNS represents a new insight into the biomedical potential of these plants.

This study aimed to determine in mice the redox changes in the encephalic regions after oral phytoextract intake and their association with tissue phenolic availability.

\section{Materials and methods}

\section{Materials and equipment}

Folin solution and xylenol orange, as well as other chemicals, were obtained from Sigma Aldrich Inc. (USA). Solvents were from Cicarelli S.A (Argentina).

Spectrophotometric readings were performed on a GloMax ${ }^{\circledR}-$ Multi microplate multimode reader (Promega Corp., USA).

\section{Plant extracts}

After the corresponding governmental consent (Cordoba MINCYT, Argentina), plant samples of LG and AQB were collected during the summer from the mountain zone of the Chaquenian phytogeographic region in Central Argentina $\left(31^{\circ} 15^{\prime} 40^{\prime \prime} \mathrm{S}\right.$, $\left.64^{\circ} 27^{\prime} 50^{\prime \prime} \mathrm{W}\right)$. The identified specimens were stored in the RIOC Herbarium (UNRC, Argentina). IP was obtained from commercial organic cultures. Ten grams of pulverized air-dried samples were extracted by adding $50 \mathrm{ml}$ of initially heated water at $95^{\circ} \mathrm{C}$. These infusions were allowed to cool at room temperature for 1 hour reaching a final temperature of $35-40^{\circ} \mathrm{C}$ (in darkness, with constant agitation). After the blends were centrifuged, extracts were recovered from each supernatant by filtration and lyophilized for 24 hours at $<-50^{\circ} \mathrm{C}$ under vacuum. Finally, the phytonutritional profiles of the extracts are as follows:

- LG: $10.23 \pm 0.43$ gallic equivalent $\mathrm{mg} / \mathrm{g}$ of dry extract (total phenolics, TP), with $58.46 \%$ of total flavonoids $(5.98 \pm 0.12$ quercetin equivalent $\mathrm{mg} / \mathrm{g})$.

- AQB: $2.57 \pm 0.14 \mathrm{mg} / \mathrm{g}$ of $\mathrm{TP}$, with $37.74 \%$ of total flavonoids $(0.97 \pm 0.06 \mathrm{mg} / \mathrm{g})$.

- IP: $21.77 \pm 1.37 \mathrm{mg} / \mathrm{g}$ of TP, with $24.48 \%$ of total flavonoids $(5.33 \pm 0.13 \mathrm{mg} / \mathrm{g}) .^{21}$

Extract antioxidant activities have been established in vitro by FRAP $(\mathrm{Fe}++\mu$ mole $/ g$ of plant $) .{ }^{5} \mathrm{LG}=$ $351.30 \pm 10.89 ; \quad \mathrm{AQB}=234.30 \pm 8.63 ; \quad$ and $\quad \mathrm{IP}=$ $1653.57 \pm 24.86$. Other specific phytochemical analyses of these plants are available. ${ }^{22-24}$

\section{Experimental conditions}

This study was carried out according to the ethical and technical US guidelines; 2-month-old Balb/c mice of both sexes were treated and sacrificed. Animals were bred under standard laboratory conditions and fed ad libitum with commercial diet $(200 \pm 13 \mathrm{~g} / \mathrm{kg} /$ day; Cargill SACI, Argentina) and potable water (150 \pm $10 \mathrm{~mL} / \mathrm{kg} /$ day; Aguas Cordobesas SA, Argentina). They were separated into four experimental groups of six animals each one to be treated in vivo (oral intake) for 1 month: $\mathrm{C}$ (water without extract), AQB, $\mathrm{LG}$, and IP (100 mg/ $\mathrm{kg} /$ day of each water-dissolved extract, equivalent to the consumption of 2 liters of infusion in humans approximately). General status, weight, food, and water consumption were controlled weekly. After the treatment, the mice were sacrificed, the organs were weighed, and divided into different regions: brain (telencephalon and diencephalon) midbrain, brainstem, and cerebellum. These tissues were mechanically homogenized to assay proteins (using the Bradford method) and $\gamma$-glutamyltranspeptidase (GGT) activity, and then extracted $(0.1 \mathrm{~g}$ of tissue in $1 \mathrm{ml}$ of $60 \%$ methanol and $2.5 \%$ trichloroacetic acid, for 30 minutes at $50^{\circ} \mathrm{C}$ ) to assay the other biochemical parameters.

\section{Determinations}

Total phenols (TP) were measured in murine tissue extracts according to the Folin-Ciocalteu technique. ${ }^{25}$ Briefly, the samples were mixed with $2 \mathrm{~N}$ Folin reactant, water, and saturated sodium bicarbonate solution $(1: 1: 6: 2 \mathrm{v} / \mathrm{v} / \mathrm{v} / \mathrm{v})$, and incubated for 30 minutes in darkness at $37^{\circ} \mathrm{C}$. Results at $750 \mathrm{~nm}$ were calculated from a standard curve of gallic acid $(0-0.1 \mathrm{mg} / \mathrm{ml})$ and expressed per protein $\mathrm{mg}$.

Aqueous and lipid peroxides (AHP and LHP, respectively) were analyzed in murine tissue homogenates. Samples were mixed with a xylenol orange-based reactant $(1: 10 \mathrm{v} / \mathrm{v})$, and incubated for 30 minutes. Then, hydroperoxide (HP) concentrations were standardized by the protein content and then expressed as percentages of absorbance $(560 \mathrm{~nm})$ with respect to control $(\%){ }^{11}$

Superoxide anion (SO) was assessed spectrophotometrically in murine tissue extracts by nitroblue tetrazolium $(1 \mathrm{mg} / \mathrm{ml})$ staining. Samples were mixed with the colorant $(9: 1 \mathrm{v} / \mathrm{v})$, and incubated for 30 minutes in darkness at $37^{\circ} \mathrm{C}$. Then, this mix was added with dimethylsulfoxide and potassium hydroxide $(2: 1: 1 \mathrm{v} / \mathrm{v} / \mathrm{v})$ before reading at $600 \mathrm{~nm}$. SO absorbance were divided per protein content and then expressed as percentage with respect to control (\%).

Specific GGT activity (EC 2.3.2.2) was measured in homogenates using the kinetic Szasz method, given its significant role in glutathione metabolism. ${ }^{26}$ Briefly, the samples were mixed with kit reactants $(\mathrm{pH} 8.25$, $100 \mathrm{mmole} / 1$ Tris buffer, 2.9 mmole $/ 1$ L- $\gamma$-glutamyl3-carboxy-4-nitroanilide, and 100 mmole/1 glycylglycine) at $25^{\circ} \mathrm{C}$. Catalytic international units were calculated by multiplying 1158 times (a constant) the 
absorbance difference/minute, divided by per protein content $(\mathrm{mIU} / \mathrm{mg})$. Then, the GGT activity was expressed as positive or negative (using technical precision criteria as cut point) under conditions of initial velocity and linearity ranges.

\section{Statistical analysis}

Data were expressed as mean \pm standard error (SE) from three separate experiments performed in triplicate. Age and body weight-fixed analysis of variance models were used to evaluate differences of tissue phenolic content, oxidation, and GGT activity (effects) among treatments (C, AQB, LG, and IP). Then, the Tukey test was used for mean comparisons, considering a significant level of $P<0.05$. Analytical probes were performed using the InfoStat 2012 software (InfoStat Group, Argentina).

\section{Results}

Encephalic TP were higher in male mice treated with LG and IP and lower with AQB extract in females $(P<0.05)$ with respect to the control $(C)$ (Fig. 1).

Moreover, the intake of the different plant extracts was associated with a general oxidative status of the CNS (Fig. 2).

\section{Brain}

\section{Telencephalon}

TP were increased by LG and IP treatments (157 and $161 \%$, respectively) $(P<0.05)$ in males, whereas TP were decreased to $42 \%$ by LG in females $(P<0.05)$ (Fig. 3). AHP were increased by LG and IP treatments $(270 \%$ in both cases) in males, and these extracts also increased them $(256 \%)$ in females $(P<0.05)$. In males, LHP were reduced by the AQB treatment $(43 \%$ with respect to controls; $P<0.05$ ).

In female mice, $\mathrm{SO}$ determinations were increased significantly $(P<0.05)$ by all treatments. The GGT

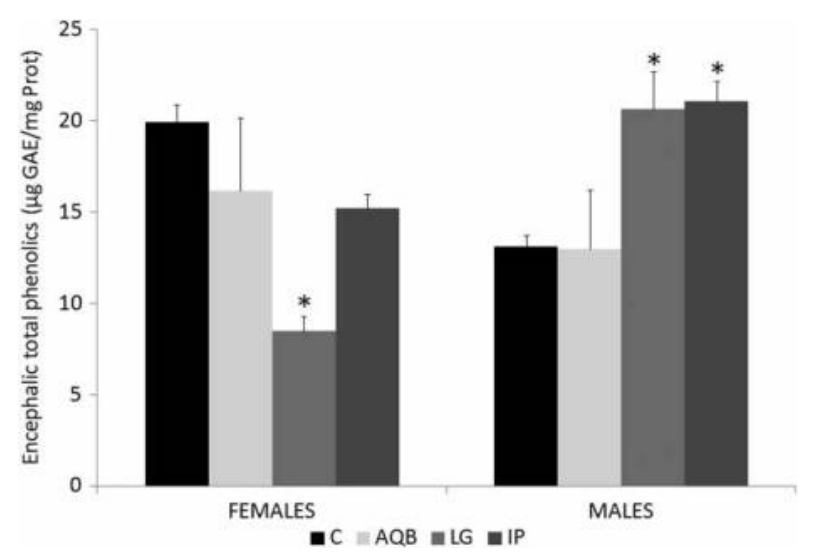

Figure 1 Encephalic total phenolics in Balb/c mice treated for a month with $0 \mathrm{mg} / \mathrm{kg} /$ day (control) or $100 \mathrm{mg} / \mathrm{kg} /$ day of each plant extract. C: control, AQB: A. quebracho-blanco, LG: L. grisebachii, IP: I. paraguariensis. Mean \pm SE are expressed as $\mu \mathrm{g}$ GAE (gallic acid equivalents) per mg proteins ( ${ }^{\star} P<0.05$ ). concentrations were elevated only in male mice treatments with the IP extract $(0.30 \pm 0.04)$ with respect to the control group $(0.07 \pm 0.03)(P<0.05)$ (Table 1$)$.

\section{Diencephalon}

The levels of TP were elevated 11 times in females treated with AQB $(P<0.05)$ (Fig. 3). In this experimental group, AHP and LHP were augmented (500 and $1600 \%$, respectively) $(P<0.05)$. On the other hand, no significant modifications with respect to $\mathrm{C}$ of these parameters were observed in males with any phytoextract treatments.

Female mice treated with AQB showed a decrease of SO $(P<0.05)$. GGT determinations were reduced by all treatments in females and were greater due to $\mathrm{AQB}$ in males $(1.12 \pm 0.00)$ with respect to the control group $(0.07 \pm 0.03)(P<0.05)$ (Table 1$)$.

\section{Midbrain}

In both sexes, TP were not detected under the different treatments, except for the AQB extract $(P<0.05)$ (Fig. 3). AHP tissue levels were elevated by all treatments: AQB, LG, and IP $(714,952$, and $476 \%$, respectively) in females $(P<0.05)$, whereas only AQB extract increased AHP by three-fold in males $(P<0.05)$. In both sexes, LHP concentrations were augmented by AQB and LG treatments (278\% in males and 313\% in females, with similar amounts with both extracts; $P<0.05)$.

SO concentrations were decreased by IP/LG and AQB $/$ LG in female and male mice, respectively $(P<$ $0.05)$. Only female mice GGT concentrations were decreased by LG and IP extracts $(0.00 \pm 0.00)$ with respect to the control group $(0.07 \pm 0.02)(P<0.05)$ (Table 1).

\section{Brainstem}

TP contents were higher in AQB and LG treatments (1.8 and $2.5 \%$, respectively, $P<0.05$ ) than $\mathrm{C}$ females and males, respectively (Fig. 3).

AHP was increased by LG (250 and 300\% in females and males, $P<0.05$ ) in both sexes while the LHP levels were elevated by LG and IP (322 and $1240 \%$, respectively, $P<0.05$ ) only in females.

$\mathrm{SO}$ was decreased in the female mice treated with LG and increased in male mice that received the AQB extract $(P<0.05)$. The GGT activity was diminished by IP $(0.04 \pm 0.01)$ and LG treatments $(0.02 \pm$ $0.00)$ with respect to the control group $(0.09 \pm 0.02)$ in female mice and only by IP extracts $(0.00 \pm 0.00)$ with respect to the control group in male mice $(0.15 \pm 0.02 ; P<0.05)($ Table 1$)$.

\section{Cerebellum}

A decrease of TP in male mice treated with $\mathrm{AQB}$ and IP was observed in relation to the $\mathrm{C}$ group (48 and $36 \%$, respectively, $P<0.05$; Fig. 3). Moreover, AHP 


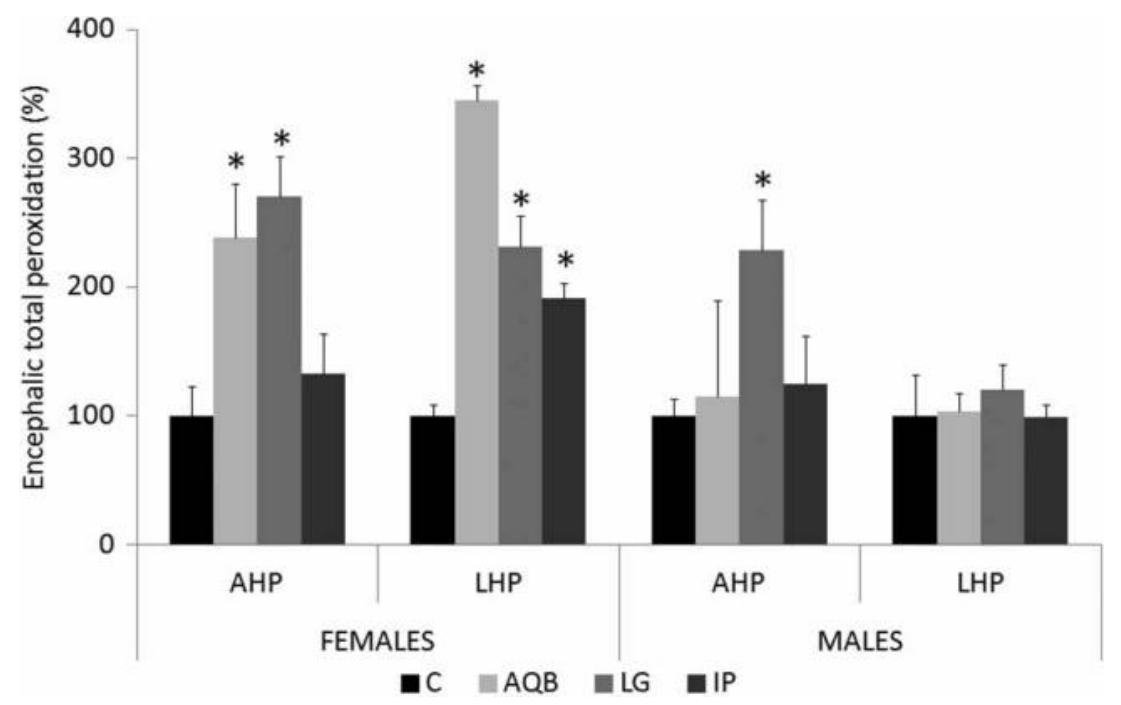

Figure 2 Encephalic total peroxidation: aqueous and lipid peroxides (AHP and LHP) in Balb/c mice treated for a month with $0 \mathrm{mg} / \mathrm{kg} /$ day (control) or $100 \mathrm{mg} / \mathrm{kg} /$ day of each plant extract. C: control, AQB: A. quebracho-blanco, LG: L. grisebachii, IP: I. paraguariensis. Mean $\pm S E$ are expressed as percentages of absorbance with respect to the control after standardizing by the protein content $(\%)\left({ }^{\star} P<0.05\right)$.
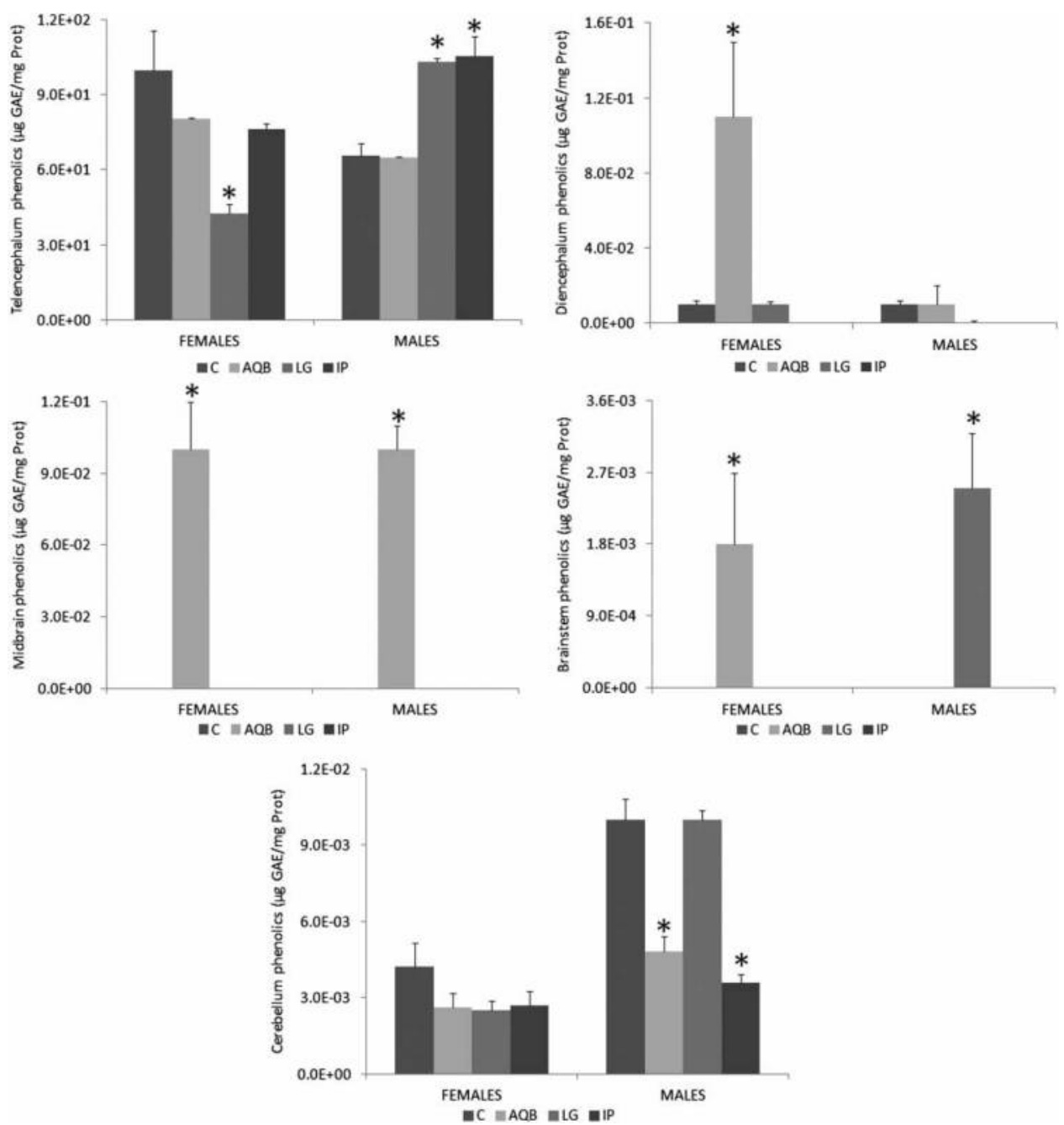

Figure 3 Total phenolics in different regions of CNS in Balb/c mice treated for a month with $0 \mathrm{mg} / \mathrm{kg} / \mathrm{day}$ (control) or $100 \mathrm{mg} / \mathrm{kg} /$ day of each plant extract. C: control, AQB: A. quebracho-blanco, LG: L. grisebachii, IP: I. paraguariensis. Mean \pm SE are expressed as $\mu \mathrm{g}$ GAE (gallic acid equivalents) per mg proteins $\left({ }^{*} P<0.05\right)$. 


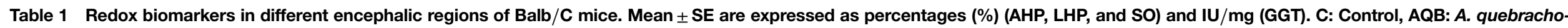
blanco, LG: L. grisebachii, IP: I. paraguariensis $\left({ }^{*} P<0.05\right)$.

\begin{tabular}{|c|c|c|c|c|c|c|c|c|}
\hline \multirow{2}{*}{ Treatments } & \multicolumn{2}{|c|}{ Aqueous peroxides (\%) } & \multicolumn{2}{|c|}{ Lipid peroxides (\%) } & \multicolumn{2}{|c|}{ Superoxide anion (\%) } & \multicolumn{2}{|c|}{ GGT activity (IU/mg) } \\
\hline & Females & Males & Females & Males & Females & Males & Females & Males \\
\hline \multicolumn{9}{|c|}{ Telencephalon } \\
\hline C & $100.00 \pm 12.82$ & $100.00 \pm 06.21$ & $100.00 \pm 00.80$ & $100.00 \pm 08.80$ & $100.03 \pm 08.72$ & $100.00 \pm 12.47$ & $0.19 \pm 0.04$ & $0.07 \pm 0.03$ \\
\hline AQB & $115.38 \pm 43.58$ & $089.18 \pm 08.10$ & $100.00 \pm 15.00$ & $043.00 \pm 11.00^{*}$ & $175.89 \pm 06.95^{*}$ & $076.15 \pm 06.15$ & $0.18 \pm 0.05$ & $0.12 \pm 0.00$ \\
\hline LG & $256.41 \pm 12.81^{*}$ & $270.27 \pm 06.21^{*}$ & $100.00 \pm 13.00$ & $100.00 \pm 13.00$ & $137.96 \pm 05.29^{*}$ & $079.00 \pm 14.75$ & $0.30 \pm 0.04$ & $0.00 \pm 0.00$ \\
\hline IP & $256.41 \pm 35.89^{\star}$ & $270.27 \pm 08.64^{*}$ & $100.00 \pm 05.00$ & $100.00 \pm 05.80$ & $177.28 \pm 21.47^{*}$ & $093.99 \pm 03.73$ & $0.10 \pm 0.02$ & $0.30 \pm 0.04^{*}$ \\
\hline \multicolumn{9}{|l|}{ Diencephalon } \\
\hline C & $100.00 \pm 04.20$ & $100.00 \pm 15.00$ & $100.00 \pm 18.80$ & $100.00 \pm 50.00$ & $099.97 \pm 05.39$ & $100.00 \pm 04.94$ & $2.11 \pm 0.93$ & $0.07 \pm 0.03$ \\
\hline AQB & $500.00 \pm 100.0^{*}$ & $034.00 \pm 06.50$ & $1600 \pm 400.00^{*}$ & $123.07 \pm 19.23$ & $070.74 \pm 09.70^{*}$ & $090.65 \pm 09.35$ & $0.00 \pm 0.00^{*}$ & $1.12 \pm 0.00^{*}$ \\
\hline LG & $200.00 \pm 48.00$ & $100.00 \pm 16.00$ & $148.00 \pm 18.00$ & $130.76 \pm 24.61$ & $075.18 \pm 13.14$ & $087.68 \pm 04.75$ & $0.00 \pm 0.00^{*}$ & $0.25 \pm 0.04$ \\
\hline $\mathrm{IP}$ & $037.00 \pm 19.00$ & $100.00 \pm 16.00$ & $064.00 \pm 19.60$ & $103.84 \pm 08.46$ & $094.72 \pm 10.07$ & $110.14 \pm 07.79$ & $0.00 \pm 0.00^{*}$ & $0.29 \pm 0.20$ \\
\hline \multicolumn{9}{|l|}{ Midbrain } \\
\hline C & $100.00 \pm 80.95$ & $100.00 \pm 14.00$ & $100.00 \pm 21.87$ & $100.00 \pm 44.40$ & $100.00 \pm 05.29$ & $100.03 \pm 15.73$ & $0.07 \pm 0.02$ & $0.20 \pm 0.03$ \\
\hline$A Q B$ & $714.28 \pm 42.85^{\star}$ & $300.00 \pm 22.00^{*}$ & $312.50 \pm 65.62^{*}$ & $277.77 \pm 36.11^{*}$ & $070.10 \pm 15.49$ & $052.57 \pm 21.11^{*}$ & $0.09 \pm 0.01$ & $0.17 \pm 0.00$ \\
\hline LG & $952.38 \pm 23.80^{*}$ & $200.00 \pm 25.00$ & $312.50 \pm 75.00^{*}$ & $277.77 \pm 18.80^{*}$ & $069.76 \pm 09.99^{*}$ & $051.80 \pm 03.84^{*}$ & $0.01 \pm 0.01^{*}$ & $0.12 \pm 0.01$ \\
\hline IP & $476.19 \pm 97.61^{*}$ & $100.00 \pm 12.00$ & $084.37 \pm 20.00$ & $086.10 \pm 15.27$ & $078.01 \pm 03.77^{\star}$ & $081.73 \pm 03.66$ & $0.00 \pm 0.00^{*}$ & $0.23 \pm 0.12$ \\
\hline \multicolumn{9}{|l|}{ Brainstem } \\
\hline C & $100.00 \pm 06.50$ & $100.00 \pm 00.33$ & $100.00 \pm 18.38$ & $100.00 \pm 46.00$ & $099.97 \pm 05.25$ & $100.00 \pm 04.50$ & $0.09 \pm 0.02$ & $0.15 \pm 0.02$ \\
\hline AQB & $100.00 \pm 20.50$ & $035.00 \pm 05.50$ & $322.58 \pm 26.12^{*}$ & $100.00 \pm 01.00$ & $106.53 \pm 03.26$ & $106.53 \pm 03.26^{\star}$ & $0.09 \pm 0.01$ & $0.16 \pm 0.04$ \\
\hline LG & $250.00 \pm 50.00^{*}$ & $300.00 \pm 39.00^{*}$ & $1240.3 \pm 54.83^{*}$ & $100.00 \pm 39.00$ & $077.16 \pm 01.80^{*}$ & $077.16 \pm 01.80$ & $0.02 \pm 0.00^{*}$ & $0.09 \pm 0.02$ \\
\hline IP & $100.00 \pm 12.50$ & $046.00 \pm 00.78$ & $695.16 \pm 100.0$ & $100.00 \pm 07.80$ & $105.44 \pm 19.26$ & $105.44 \pm 19.26$ & $0.04 \pm 0.01^{*}$ & $0.00 \pm 0.00^{*}$ \\
\hline \multicolumn{9}{|l|}{ Cerebellum } \\
\hline C & $100.00 \pm 08.70$ & $100.00 \pm 08.40$ & $100.00 \pm 04.54$ & $100.00 \pm 12.00$ & $100.04 \pm 15.36$ & $099.95 \pm 16.21$ & $0.00 \pm 0.00$ & $0.00 \pm 0.00$ \\
\hline AQB & $100.00 \pm 03.80$ & $100.00 \pm 01.50$ & $227.27 \pm 88.63$ & $100.00 \pm 14.00$ & $080.07 \pm 15.24$ & $084.56 \pm 32.27$ & $0.03 \pm 0.01$ & $0.19 \pm 0.07$ \\
\hline LG & $100.00 \pm 06.40$ & $300.00 \pm 28.00^{*}$ & $227.27 \pm 59.09$ & $100.00 \pm 07.00$ & $121.59 \pm 14.50$ & $106.48 \pm 30.56$ & $0.00 \pm 0.00$ & $0.09 \pm 0.01$ \\
\hline IP & $100.00 \pm 18.00$ & $200.00 \pm 32.00^{*}$ & $227.27 \pm 52.27$ & $100.00 \pm 09.50$ & $080.07 \pm 15.24$ & $107.57 \pm 09.22$ & $0.14 \pm 0.05^{\star}$ & $0.07 \pm 0.01$ \\
\hline
\end{tabular}


was raised by LG and IP treatments (200 and 300\%, respectively, $P<0.05$ ) in males although extract effects were not statistically significant on LHP concentration with respect to C. SO was unaffected, whereas the GGT concentration was increased by IP $(0.14 \pm 0.05)$ with respect to the control group $(0.00 \pm 0.00)$ in female mice $(P<0.05$; Table 1$)$.

\section{Discussion}

In the present work, wide variations were observed in the redox state of the studied encephalic regions of mice after each phytoextract intake.

The first plant considered was IP because it is the main species consumed by humans in South America with approximate values of 2 liters per day. ${ }^{22}$ Concerning the redox markers used, $\mathrm{SO}$ is a transient precursor of different HP (initial aqueous forms, such as hydrogen peroxide) and lipoperoxides (later organic derivatives). This chain reaction was induced by IP consumption in the murine cerebellum and brain of both sexes, with telencephalon being affected, whereas initiation of this oxidative pathway was prevented subcortically. This differential redox susceptibility of the brain cortex has been established previously in phytonutritional approaches. Moreover, the tissue GGT activity was consistent with these changes, thus confirming the cellular stress response. ${ }^{26}$

The phenolic augmentation in male telencephalon was due to their high systemic bioavailability, ${ }^{21}$ which favored their passage through $\mathrm{BBB}^{6,8}$ This finding is similar to other studies that demonstrate the capacity of infusion-derived phenolics to concentrate in the CNS after oral intake. ${ }^{2}$ However, this effect was not linked to the observed redox modifications. Thus, these outcomes might respond to other BBB-permeable excitatory compounds present in $\mathrm{IP}^{22}$ In fact, this experimental group showed increased diurnal wakefulness, ${ }^{21}$ which in turn may predispose to cortical oxidation without affecting the other brain regions. ${ }^{27}$

The sexual differences in phenolic concentration were seen in the telencephalon and brainstem of animals that consumed LG, leading to an imbalance in both cases: deficiency in female mice and accumulation in male ones, which in turn might cause redox disturbances. ${ }^{28}$ Since the oral bioavailability and phytochemical profile were the same for both sexes, ${ }^{21}$ it was inferred that active transport processes were opposed in males (influx) and females (efflux/clearance). However, specific mechanisms are unknown. Nevertheless, the encephalic GGT inhibition in females could be involved. This enzyme is a structural and functional marker of the $\mathrm{BBB},{ }^{29,30}$ since it promotes barrier permeability and water fluxes, ${ }^{31}$ key for infusion-derived compounds. Thus, its lesser catalytic activity, usually observed in female tissues, ${ }^{32}$ might explain the phenolic reduction found here. Furthermore, LG consumption has proved to inhibit GGT in rats. ${ }^{24}$ The intake of this plant extract was associated with a general oxidative status of the CNS, which was expected in accordance with previous results. ${ }^{24}$

The AQB treatment induced phenolic redistribution in female encephalon leading to subcortical increases (brain, midbrain, and brainstem), which was related to peroxyl triggering. ${ }^{28}$ Moreover, females showed a residual oxidative effect in the telencephalon. Otherwise, males responded to this extract to less extent, with redox imbalance being only mesencephalic. The sex-related pharmacokinetic features of phenolics may explain their increase in female encephalon with respect to males (with high metabolism and clearance). ${ }^{33}$

On the other hand, the cerebellum was less responsive to the different extract treatments than the supratentorial organs of both sexes.

Although plant polyphenols have been proposed as a panacea for human health, ${ }^{34}$ the appropriate phenolic concentration in CNS tissues is a critical factor in order to maintain redox homeostasis in mice, given that deficient or excessive levels are deleterious (mainly under situations without exogenous challenges), leading to oxidative stress independently of the utilized phytoextracts. Among them, LG and AQB caused this phenolic imbalance and exhibited oxidizing effects. Then again, IP showed differential region-specific redox effects; however, this extract showed the best redox profile when complete encephalon was analyzed. In accordance to these results and given the massive IP consumption by humans, ${ }^{22}$ this plant could be a source of chemopreventive agents for oxidative stress-related neurodegenerative pathologies with high sanitary impact. Thus, new studies about it are warranted.

\section{Disclaimer statements Contributors}

The four authors participated in the design, experiments, redaction and critical revision of the manuscript.

\section{Funding}

None.

\section{Conflicts of interest}

None.

\section{Ethics approval}

None.

\section{Acknowledgements}

This study was financially supported by the SECYT (National University of Cordoba, Argentina) and the 
INC (National Ministry of Health), with the authors declaring that there were no conflicts of interest. Authors thank Garrett Gardner, a native English speaker, and Daniela Defagó PhD (Harvard School of Public Health, USA) for critical revision of the manuscript.

\section{References}

1 Halliwell B, Whiteman M. Measuring reactive species and oxidative damage in vivo and in cell culture: how should you do it and what do the results mean? Br J Pharmacol 2004;142:231-55.

2 Andrade JP, Assuncao M. Protective effects of chronic green tea consumption on age-related neurodegeneration. Curr Pharm Des. 2012;18:4-14.

3 Linardaki ZI, Vasilopoulou CG, Constantinou C, Iatrou G, Lamari FN, Margarity M. Differential antioxidant effects of consuming tea from Sideritis clandestina subsp. peloponnesiaca on cerebral regions of adult mice. J Med Food 2011;14:1060-4.

4 Albarracin SL, Stab B, Casas Z, Sutuchan JJ, Samudio I, Gonzalez J, et al. Effects of natural antioxidants in neurodegenerative disease. Nutr Neurosci 2012;15:1-9.

5 Borneo R, León AE, Aguirre A, Ribotta P, Cantero JJ. Antioxidant capacity of medicinal plants from the Province of Córdoba (Argentina) and their in vitro testing in a model food system. Food Chem 2009;112:664-70.

6 Vauzour D, Rodriguez-Mateos A, Corona G, Orunda-Concha MJ, Spencer JP. Polyphenols and human Health: prevention of disease and mechanism of action. Nutrients 2010;2:1106-31.

7 Haque AM, Hashimoto M, Katakura M, Tanabe Y, Hara Y, Shido O. Long-term administration of green tea catechins improves spatial cognition learning ability in rats. J Nutr 2006; 136:1043-7.

8 Vasilopoulou CG, Kontogianni VG, Linardaki ZI, Iatrou G, Lamari FN, Nerantzaki AA, et al. Phytochemical composition of 'mountain tea' from Sideritis clandestina subsp. clandestina and evaluation of its behavioral and oxidant/antioxidant effects on adult mice. Eur J Nutr 2013;52:107-16.

9 Campos-Esparza MR, Sánchez-Gómez MV, Matute C. Molecular mechanisms of neuroprotection by natural antioxidant polyphenols. Cell Calcium 2009;45:358-68.

10 Gomez-Pinilla F, Nguyen TT. Natural mood foods: The actions of polyphenols against psychiatric and cognitive disorders. Nutr Neurosci 2012;1:127-33

11 Soria EA, Goleniowski ME, Cantero JJ, Bongiovanni GA. Antioxidant activity of different extracts of Argentinian medicinal plants against arsenic-induced toxicity in renal cell. Hum Exp Toxicol. 2008;27:341-6.

12 Manach C, Williamson G, Morand C, Scalbert A, Rémésy C. Bioavailability and bioefficacy of polyphenols in humans. I. Review of 97 bioavailability studies. Am J Clin Nutr 2005;81(Suppl 1):S230-42.

13 Singh M, Arseneault M, Sanderson T, Murthy V, Ramassamy C. Challenges for research on polyphenols from foods in Alzheimeŕs disease: bioavailability, metabolism, and cellular and molecular mechanisms. J Agric Food Chem 2008;56: 4855-73.

14 Ebrahimi A, Schluesener H. Natural polyphenols against neurodegenerative disorders: potentials and pitfalls. Ageing Res Rev 2012;11:329-45.

15 Pandey KB, Rizvi SI. Plant polyphenols as dietary antioxidants in human health and disease. Oxid Med Cell Longev 2009;2: 270-8.

16 Spencer JP, Abd El Mohsen MM, Minihane AM, Mathers JC. Biomarkers of intake of dietary polyphenols: strengths, limitations and application in nutrition research. Br J Nutr 2008;99: $12-22$.
17 Vauzour D. Dietary Polyphenols as modulators of brain functions: biological actions and molecular mechanisms underpinning their benificial effects. Oxid Med Cell Longev [serial online]. 2012 [cited 2013 Dec 11]; 914273. Available from: http ://www.hindawi.com/journals/omcl/2012/914273/.

18 Abd El Mohser MM, Kuhnle G, Rechner AR, Schroeter H, Rose S, Jenner P, et al. Uptake and metabolism of epicatechin and its access to the brain after oral ingestion. Free Radic Biol Med 2002;33:1693-702.

19 Bastianetto S, Yao ZX, Papadopoulos V, Quirion R. Neuroprotective effects of green and black teas and their catechin gallate esters against beta-amyloid-induced toxicity. Eur J Neurosci 2006;23:55-64.

20 Goleniowski ME, Bongiovanni GA, Palacio L, Nuñez CO, Cantero JJ. Medicinal plants from the 'Sierra de Comechingones', Argentina. J Ethnopharmacol 2006;107: 324-41.

21 Canalis AM, Cittadini MC, Albrecht C, Soria EA. Sex-related redox effects of Aspidosperma quebracho-blanco, Lantana grisebachii and Ilex paraguariensis on blood, thymus and spleen of mice. Indian J Exp Biol, in press 2014.

22 Bracesco N, Sanchez AG, Contreras V, Menini T, Gugliucci A. Recent advances on Ilex paraguariensis research: minireview. J Ethnopharmacol 2011;136:378-84.

23 Deutsch HF, Evenson MA, Drescher P, Sparwasser C, Madsen PO. Isolation and biological activity of aspidospermine and quebrachamine from an Aspidosperma tree source. J Pharm Biomed Anal 1994;12:1283-7.

24 Ramos Elizagaray SI. Actividad quimiopreventiva e inmunoprotectora del extracto acuoso de Lantana grisebachii Seckt. vargrisebachii en hidroarsenicismo experimental. [MD Thesis]. Córdoba, Argentina: Universidad Nacional de Córdoba; 2013.

25 Ait Baddi G, Cegarra J, Merlina G, Revel JC, Hafidi M. Qualitative and quantitative evolution of polyphenolic compounds during composting of an olive-mill waste-wheat straw mixture. J Hazard Mater 2009;165:1119-23.

26 Quiroga A, Quiroga PL, Martínez E, Soria EA, Valentich MA. Anti-breast cancer activity of curcumin on the human oxidationresistant cells ZR-75-1 with gamma-glutamyltranspeptidase inhibition. J Exp Ther Oncol 2010;8:261-6.

27 Gonçalves J, Baptista S, Silva AP. Psychostimulants and brain dysfunction: a review of the relevant neurotoxic effects. Neuropharmacology, in press 2014.

28 Samsel A, Seneff S. Glyphosate's suppression of cytochrome P450 enzymes and amino acid biosynthesis by the gut microbiome: pathways to modern diseases. Entropy 2013;15: 1416-63.

29 Kido Y, Tamai I, Nakanishi T, Kagami T, Hirosawa I, Sai Y, Tsuji A. Evaluation of blood-brain barrier transporters by coculture of brain capillary endothelial cells with astrocytes. Drug Metab Pharmacokinet 2002;17:34 41.

30 Vandenhaute E, Dehouck L, Boucau MC, Sevin E, Uzbekov R, Tardivel M, et al. Modelling the neurovascular unit and the blood-brain barrier with the unique function of pericytes. Curr Neurovasc Res 2011;8:258-69.

31 Welbourne TC, Dass PD. Function of renal gamma-glutamyltransferase: significance of glutathione and glutamine interactions. Life Sci 1982;30:793-801.

32 Goldberg DM. Structural, functional, and clinical aspects of gamma-glutamyltransferase. CRC. Crit Rev Clin Lab Sci 1980; 12:1-58.

33 Li QS, Xi H, Han GZ, Wang CY, Lü L, Zou LL, Li N. Integrated pharmacokinetic study of multiple effective components of tea polyphenols and its correlation with anti-free radical pharmacodynamics in rats. Yao Xue Xue Bao 2012;47: 863-9.

34 Dani C, Oliboni LS, Agostini F, Funchal C, Serafini L, Henriques JA, et al. Phenolic content of grapevine leaves (Vitis labrusca var. Bordo) and its neuroprotective effect against peroxide damage. Toxicol In Vitro 2010;24:148-53. 